Article

\title{
Dynamic Authenticity: Understanding and Conserving Mosuo Dwellings in China in Transitions
}

\author{
Huichao Feng ${ }^{1, *}$ and Jieling Xiao ${ }^{2}(\mathbb{D}$ \\ 1 Department of Environmental Design, School of Art and Design, Zhejiang Sci-Tech University, \\ Hangzhou 310018, China \\ 2 School of Architecture and Design, Birmingham City University, Birmingham B5 5JU, UK; \\ jieling.xiao@bcu.ac.uk \\ * Correspondence: fenghc@zstu.edu.cn; Tel.: +86-137-380-10842
}

check for

updates

Citation: Feng, H.; Xiao, J. Dynamic Authenticity: Understanding and Conserving Mosuo Dwellings in China in Transitions. Sustainability 2021, 13, 143. https://dx.doi.org/ $10.3390 /$ su13010143

Received: 23 November 2020 Accepted: 22 December 2020 Published: 25 December 2020

Publisher's Note: MDPI stays neutral with regard to jurisdictional claims in published maps and institutional affiliations.

Copyright: () 2020 by the authors. Licensee MDPI, Basel, Switzerland. This article is an open access article distributed under the terms and conditions of the Creative Commons Attribution (CC BY) license (https: / / creativecommons.org/ licenses/by/4.0/).

\begin{abstract}
Mosuo dwellings are distinctive vernacular architecture forms that are shaped by the unique matriarchal society of Mosuo in Southwest China. They have undergone dramatic transformations during the 21st century as a result of modernization and tourism. There is a lack of theoretical and empirical studies regarding the impact on the authenticity. This paper aims to fill this gap and develops a theoretical framework - cultural architectural assets- to understand and interpret the transitions of Mosuo dwellings and their authenticity in transitions. Adopting an anthropological methodology approach, this article examines the changes and continuities of Mosuo dwellings during the last thirty years. Fieldwork was conducted in nine Mosuo villages in Yongning Township through a range of qualitative methods, including participatory observations, photographic survey and photo elicitation interviews. The investigation results revealed cultural-architectural elements that are continued in the transitions include the courtyard form, the sacred chamber and the grandmother's house; cultural-architectural elements that are changing include the flower house and grass house; cultural-architectural elements that are disappearing include the back room (Dupan) and the upper hearth in the grandmother's house as well as the wooden shingle roof. As a result, the study constructs a conservation approach for sustainable development in three dimensions: living culture, building culture and values and beliefs. This analytical framework can be adapted to be applied to different contexts as a sustainable approach for the conservation and development of vernacular architecture in transitions.
\end{abstract}

Keywords: dynamic authenticity; vernacular architecture in transition; cultural architectural asset; sustainable conservation; mosuo dwellings

\section{Introduction \\ 1.1. Research Context}

Known as "the Kingdom of Women", the Mosuo people are one of the few remaining matriarchal societies in the world. They are mainly distributed in the Yongning basin and surrounding areas: Around the Lugu Lake of the Ninglang District in Yunnan Province, and to the west of the Yanyuan District in Sichuan Province [1]. In their culture, Mosuo women are the head of the household; as the decision-makers, women are in charge of day-to-day activities, and control all property and money within the family [2]. Instead of a civil marriage, the Mosuo have "walking marriages" ("Zouhun" in Chinese), an ongoing sexual relationship based on mutual affection [3]. Men usually visit their lovers at night in the woman's house, and return to their own maternal family in the early morning [4]. There is no marriage contract in any real sense, and the offspring resulting from these unions are taken and raised by the women and their clans [5]. They neither share a residence, nor have economic relations, with their partners. The Mosuo practice two religions simultaneously: Tibetan Buddhism, and their native religion Daba [6]. 
Mosuo dwellings are productions of the Mosuo culture and their unique ways of living - a living representation of cultural forms, with rules, rituals and meanings embodied in it. Due to the special matrilineal consanguinity, the spatial layout of a Mosuo dwelling tends to include a large courtyard surrounded by four buildings, arranged in a square [7]. All members of a courtyard house belong to the same matrilineal descent group, usually with three or even more generations living together as a large and extended family. Some Mosuo dwellings contain as few as seven or eight family members, while others have as many as 20 or 30 . As noted in the historical record [8]:

"Most Moxie (referring to the Mosuo) live on the hillside; the houses are built of timber; the walls are made of logs, which fit together perpendicularly through notches at each end; the roof has two gentle slopes, and the wood shingles are held down by stones."

Each building has a name and specific function: the Yimi (the single-story main building, known as the Grandmother's house), the Galayi (the Sacred chamber), the Nizhayi (a two-storey structure for adult Mosuo women, known as the flower house) and the Zuowo (for storing grass and domestic animals, and known as the grass house). Shih and Cai suggest the Mosuo architectural structures and residential arrangements are compatible with matrilineal culture, walking marriages, religious beliefs and economic activities relating to daily life $[9,10]$. The Grandmother's house, as the core cultural-centre of the whole courtyard, has multiple functions as a site of worship, etiquette, gathering, dining, relaxation, etc. It is also the sleeping room for the elderly female members and young children of the household [11]. The sacred chamber is a space reserved for religious practice, which is the result of the strong influence of Tibetan Buddhism. The flower house is the direct product of the walking marriage system, and is a private space for adult female Mosuo. The grass house was formed in order to adapt to plough-based agriculture production. Thus, the Mosuo have established their own dwellings, and the spatial organisation of those dwellings, to fit in with the culture of their productive life [12].

The early study of traditional dwellings in China are limited to physical forms, such as the classification, listing and description of various building types and their features, as well as the selection of architectural materials. In the 1930s, the research on Chinese traditional architecture led by the Society for the Study of Chinese Architecture was carried out in southwest China [13] "Chinese Traditional Residence" wrote by Liu Dunzhen that is the first book to sort out the history and analyse the types of Chinese dwellings [14]. Although these studies have provided valuable basic data for later studies, they lack theoretical basis and only focus on regional and type studies.

The research on vernacular architecture broadens the scope of architecture beyond function and aesthetics, extending from physical forms to social and cultural context. Proposed by architect Bernard Rudofsky in 1964 [15], it was commonly referred to as "architecture without architects." Study of vernacular architecture was initiated by anthropologists to gain further understandings of vernacular culture and vernacular society. Lewis Henry Morgan [16] in his publication of "Houses and House Life of the American Aborigines" attempted to analyse house forms, in terms of kinship structures and social organisation. Early representative examples included Amos Rapoport's House Form and Culture. Rapoport [17] studied a large number of traditional houses and proposed that house form is the consequence of a whole range of factors, among which the socio-cultural factors are primary and others (climate conditions, methods of construction, materials available and technology) are secondary as the modifying factors. In the 1990s there was an increase in the analysis of cosmological and symbolic ideas embodied in the architectural structure and residential arrangements within the vernacular built environment. Weng [18] analysed and interpreted the construction of Mosuo gender culture "as it is symbolized in the understanding of time and space implied by their myths, the mother house, zodiac and orientation." Waterson discussed the social and symbolic aspects of houses in South-East Asia and analysed the technological and cosmological considerations behind architectural style [19]. In recent years, studies of vernacular architecture have drawn on the knowledge of many disciplines such as anthropology, historical and cultural geography, art and archi- 
tectural history, social history, folklore and sociology, such as Pan [20], Gao and Pitts [21]. Such studies suggest an interrelationship between culture, the people's ways of living and their dwellings.

Mosuo dwellings have been undergoing a transformation, in which traditional and modern architectural elements are combined to form a hybrid. "China's Traditional Rural Architecture: A Cultural Geography of the Common House" [22] was the first book in English to survey the evolution, variety, construction techniques, social context, and contemporary transformations of Chinese dwellings. It included over 200 photographs and drawings that drew attention to the richness of Chinese folk traditions, but the book is a preliminary glimpse, not a definitive treatment, of the topic. Research on Mosuo dwellings has focused on understanding and preserving the traditional aspects of Mosuo dwellings such as 'house form', 'spatial layout', and 'decoration' by conducting measurements and by mapping the original built forms $[23,24]$. However, few studies have looked at the changes and transformations of traditional ways of living and associated architectural forms in Mosuo villages in relation to modern influences. It appears that insufficient research has investigated the changes of Mosuo dwellings in transitions regarding the authenticity and building culture. In this respect, the purpose of this study is to attempt to establish a new framework for the future conservation of the architectural assets belonging to this unique vernacular architecture, so as to conserve the living culture, architectural form and cultural values embodied in Mosuo dwellings within the changing context of modernity.

\subsection{Authenticity in Heritage Conservation}

Following the physical changes in historic environments, the authenticity concept was used as a tool for conserving cultural heritage [25]. The word "authenticity" origins from Latin, derived from authentique. Authenticity refers to original, true, inimitable, legally valid, implausible beliefs, representing the first author or source. To date, its meaning has slightly changed by a semantic shift to meaning "different, exotic, romantic ambient, historic parts, etc. [26]". In heritage conservation, the notion of authenticity was defined as "the capability of the property to transmit the cultural significance of a place [27]." The consideration of authenticity in conservation practice serves to judge the values attributed to vernacular architecture. In 1964, the Venice Charter was the first international document that referred to the idea of authenticity of cultural heritage, highlighting historic values as the central concept of authenticity. It emphasised that: "... The common responsibility to safeguard them (historic monuments) for future generations is recognized. It is our duty to hand them on in the full richness of their authenticity [28]."

Subsequently, discussions have been raised about the identification and assessment of authenticity in heritage research and conservation practice. In the 1972 United Nations Educational, Scientific and Cultural Organization (UNESCO) World Heritage Convention introduced authenticity of monuments for the world heritage list nomination [29]. Gradually, Article 9 of the 1977 World Heritage Operational Guidelines stated that " ... the property should meet the test of authenticity in design, materials, workmanship and setting [30]." The measure of authenticity was first used as the initial criterion for assessment of the property in the World Heritage List. Following from that, the Nara Conference on Authenticity in 1994 verified the significance of socio-cultural values as the main criterion to explain authenticity and the process of conservation [31]. For the first time, the Nara Charter considered the importance of intangible and associated aspects of heritage. Later, criteria for assessing the measure of authenticity were introduced in the 2005 World Heritage Convention [32]: "form and design, materials and substance, use and function, traditions and techniques, location and setting, and spirit and feeling, and other internal and external factors." The concept of authenticity is about four parameters: design, materials, workmanship and setting, and these four parameters basically referred to the tangible and physical aspects of heritage. It later provided a practical basis for examining the authenticity of properties proposed for in the World Heritage List. 
Hereafter, authenticity became a unique notion of heritage conservation, and figured as the required criteria for the conservation and management of cultural heritage as well. It was adopted in local and international charters and guidelines on architectural conservation in Europe, South and East Asia. So far, the concept of authenticity serves to recognise and assess cultural heritage within a certain period of time. Thus, the concept of authenticity needs be constantly redefined and transformed to suit new cultural contexts and local concerns. The authenticity in Mosuo dwellings and culture revealed in this study is a dynamic that changes over time.

\subsection{Key Concept: Cultural Architectural Assets}

Henri Lefebvre holds that the production of space is divided into three dialectically dimensional processes: perceived, conceived and lived space [33]. His three-dimensional dialectic theory is adopted to form the theoretical framework of this paper-cultural architectural assets-for analysing interrelationships between architectural form, ways of living and culture in the process of change (Figure 1). It views cultural components as comprising living culture, building culture and values and beliefs, each of which are interrelated parts and cannot be analysed out of context. Culture is the concept in the framework relating to the vernacular architecture, and the traditional values and beliefs that are embedded in buildings and everyday use are part of that culture.

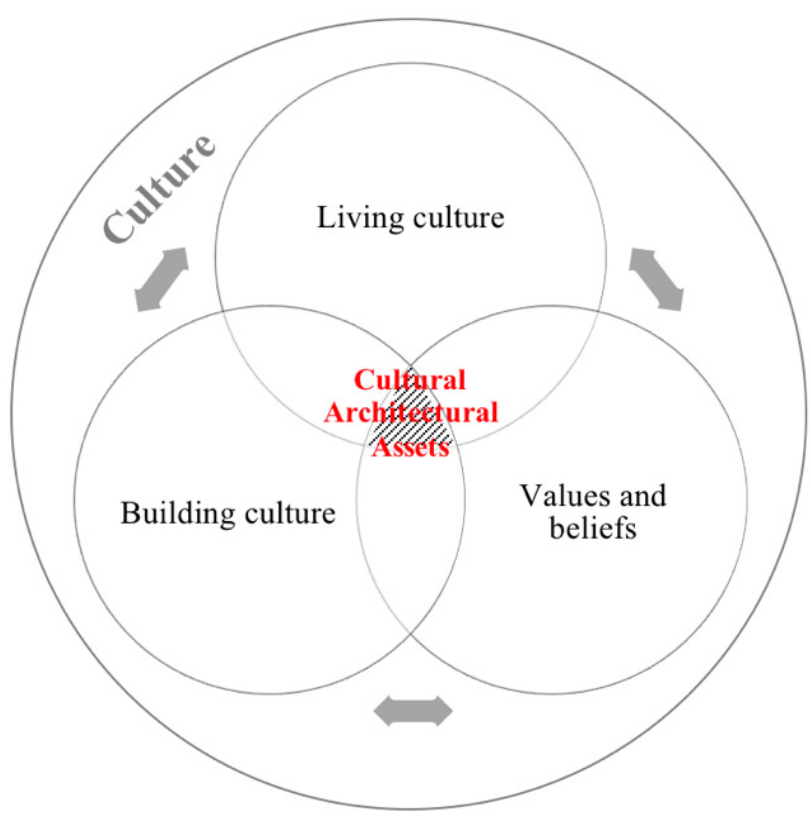

Figure 1. Cultural architectural assets are the result of the triple interrelation between living culture, building culture and values.

Culture is a very broad concept and has a diversity of definitions. One of the most influential definitions was written by Edward Tylor in 1871 [34], in his book Primitive Culture, where the term 'culture' was defined as a "complex whole which includes knowledge, belief, art, moral law, custom, and any other capabilities and habits acquired by man as a member of society." In this definition, culture can be regarded as the whole complex of distinctive material—including spiritual and intellectual material—that characterises a community, society or social group. It includes not only arts and literature but also beliefs, values, traditions and behaviour. Paul Oliver [35] states that every culture has its own forms of dwelling, built by the people who inhabit those dwellings, in a clear response to the society's physical, social and psychological needs, and as shaped as much by belief systems and concepts of status, territory and security as by economy, material resources, technology and climatic conditions. 
There are several theoretical approaches regarding culture that might be considered in determining culture's relevance to vernacular architecture. An influential framework concerning the methodology of culture study from both material and intangible aspects was introduced by Malinowski in his A Scientific Theory of Culture (1944), where he views culture as a process involving the material aspects of culture, namely, artefacts, human social relations and symbolic acts [36]. In 2005, Amos Rapoport proposed a framework to systemize culture-built environment relations [37]. He states that culture can be dismantled into small components and become variable in two ways. One way is that culture can be specified into elements associated with certain aspects of the architecture, like world views, values, lifestyle and an activity system. Another way culture can be extracted is into tangible elements that are more observable, like kinship, family structures, roles, etc.

Cultural architectural assets (CAA) will be explained in the following parts related to empirical investigations. Living culture is a reflection of culture in the vernacular environment. Ways of living, family structure and kinship are examined as the components of living culture within the scope of this study. Activities are a more specific aspect of ways of living, such as domestic, social and religious activities [38,39]. Family structure mainly affects the required activities of the architectural form, determines the function of the room, and affects the spatial organisation of the building regarding the associated type of activities [17,40]. Building culture, as another reflection of culture in the built environment, can be examined in terms of site, spatial organisation, building structures and constructions, and interior decoration settings [41]. Values and beliefs in this study mean a set of values and beliefs about "how to behave or do things" within a group or society [42,43]. Values are one of the primary aspects of a culture system, and cultural systems rely on a series of values rather than a single dominant value [44].

\section{Methodology and Data Collection}

\subsection{An Integrative Anthropological and Architectural Approach}

This study adopts an integrative anthropological and architectural approach to investigate the interrelationships between the built form and the culture of the Mosuo in the evolution process. In addition to architectural methods, such as mapping and measurement, it also employs anthropological methods, including participatory observation and semi-structured interviews. Waterson [19] notes that in the last 20 years or so, indigenous architectures have become the subject of a growing literature by both architects and anthropologists, yet the two disciplines are not taken together as an integrated approach. According to Oranratmanee [45], anthropology and architecture lie closely in their studies, yet have different focuses, strengths and weaknesses. The anthropological approach allows researchers to spend time establishing relationships and gaining acceptance in the Mosuo villages $[46,47]$. The architectural approach emphasises the spatial relationship between people and places, which is used to visualise and decode the dynamic relationship in the dwellings [48]. When anthropology and architecture are taken together in academic studies, it can provide fruitful perspectives about the dynamic interrelationship of architectural forms and social aspects of a setting.

\subsection{Fieldwork in Yongning Region}

The research area of the study is limited to Mosuo villages in the Yongning region, in the Yunnan Province of southwest China. The fieldwork was undertaken over 41 days, from July-August in 2016. To understand the changes occurring, this research was underpinned by a comprehensive survey of nine Mosuo villages (Figure 2). The reason for selecting nine different Mosuo villages with varied geographical scope was in order to maintain a certain degree of generality and diversity in the collection of data. 


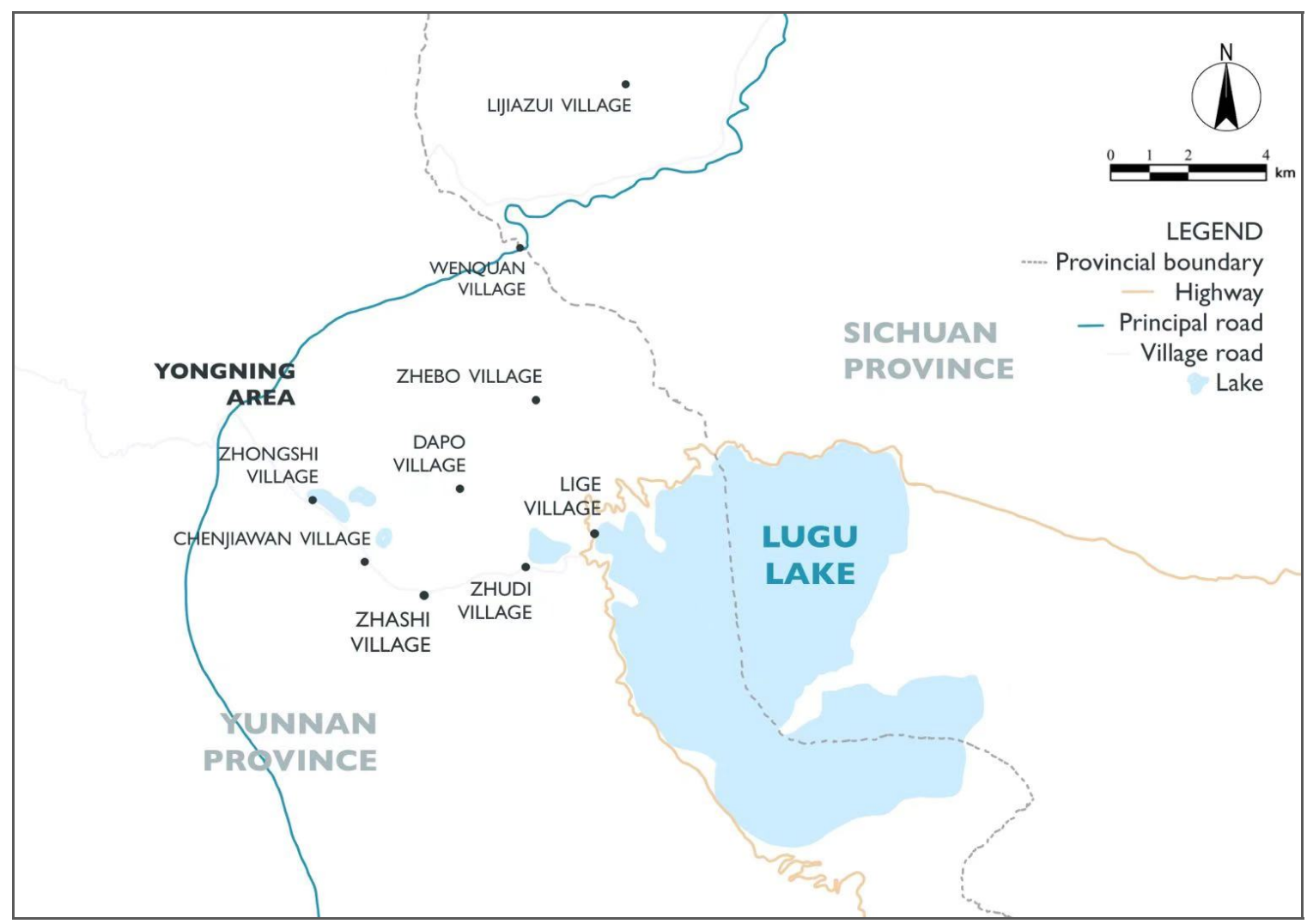

Figure 2. Location of investigated villages in Yongning region, including Zhashi village, Zhongshi village, Chenjiawan village, Lige village, Dapo village, Zhudi village, Zhebo village, Wenquan village in Yunnan Province, and Lijiazui village in Sichuan Province (Adapted from Google map, 2016).

Geographically, the Yongning region was chosen because the majority of ethnic villages around this region of Yunnan Province are dominated by the Mosuo people. Most local residents are Mosuo, making up 50\% of the local population in the Yongning region [49]. Another reason for selecting this area lies in the fact that ethnic tourism in the Lugu Lake area was explored in the 1990s in the wake of the Reform and Opening-Up Policy in China [50]. After that, tourism development in the Lugu Lake area made it a landmark in Yunnan Province, especially in the cases of the villages of Luoshui and Lige. Although the degree of tourism development varies among these Mosuo villages, within the last two decades the villages in the Yongning region have all started to become more involved in modernisation and tourism, and have become targets for further development. This study focusses on those ethnic Mosuo villages which are to be developed in the Yongning region.

\subsection{Methods Used in the Research}

\subsubsection{Participatory Observations}

Participatory observations require the researcher to immerse herself or himself in a research "setting" in which they can experience and observe at first hand a range of dimensions in and of that setting [51]. In order to get a sense of Mosuo dwellings and its culture, the author conducted participatory observations to live with the local family in the Zhashi village for over one month, during which I was able to observe Mosuo inhabitants' daily routine and activities within the dwellings (e.g., a three-day traditional Mosuo funeral ceremony). The physical architectural features and use of space in a dwelling were also gathered through physical observations.

The observations in the study focus on the following actions of inhabitants: What daily routines are there in the Mosuo dwellings? How do the locals interact with their own space? When do people eat? When do they sleep? What is the spatial arrangement of 
Mosuo dwellings, the function of each space and the decoration of each dwelling? How have changes happened to the original Mosuo dwellings? How do these changes influence the lifestyle of residents of the dwellings?

\subsubsection{Photographic Survey}

Photographic survey means "a precise machine-made record of a scene or subject [52]," which was used to collect data relevant to visual information in this study. To understand the physical changes of Mosuo dwellings, a digital camera was used to record the physical architectural features, daily activities and use of space in a dwelling. In addition, data relevant to how changes occurred to the original Mosuo dwellings, and the influence these changes had upon the ways of living of inhabitants of their dwellings, were also collected through photographs. These photographic records supported the photo elicitation interviews to provide a foundation for analysing the evolution of dwellings.

\subsubsection{Photo Elicitation Interviews}

Photo elicitation is a research method of using photographs in interviews [53], the author conducted photo elicitation interviews of selected Mosuo family members to further analyse how the Mosuo inhabitants responded to the meanings of the photographs. Photographs evoke information, feelings and memories in ways different from or supplemented by those obtained through verbal inquiry [54]. The choice of family interviews instead of individual interviews was made because the family is intrinsically important to the Mosuo people. Mosuo matriarchal society is based on a household orientation, the household is the core of cultural values, and their courtyard dwellings are built based on their cultural values [55].

In particular, the participant in the photo elicitation interview was given a booklet to browse that showed selected photos showing traditional and current Mosuo dwellings and villages (Figure 3). Most of the photos in the booklet were taken during the fieldwork, but a few are archived photos from the Mosuo museum in Sichuan Province and the Mosuo Folk Custom Museum in Yunnan province, the National Library of China in Beijing and from historical literature. The participant then was asked to select photos, then answered questions and related stories linked to the photos they had selected. Questions included: Are there any photos you prefer in the booklet and why? Do these photos evoke memories or stories? Are there any photos you do not like, and why? Which photos do you think are the most representative of Mosuo dwellings? They may have also been asked about the reasons why they did not choose other photos. It took two or three days in total to conduct the interviews for each family, and the time allocated for each interview was one-hour. These investigations provided more insights into the transitions and the relationships between the dwellings, inhabitants and the Mosuo culture. 


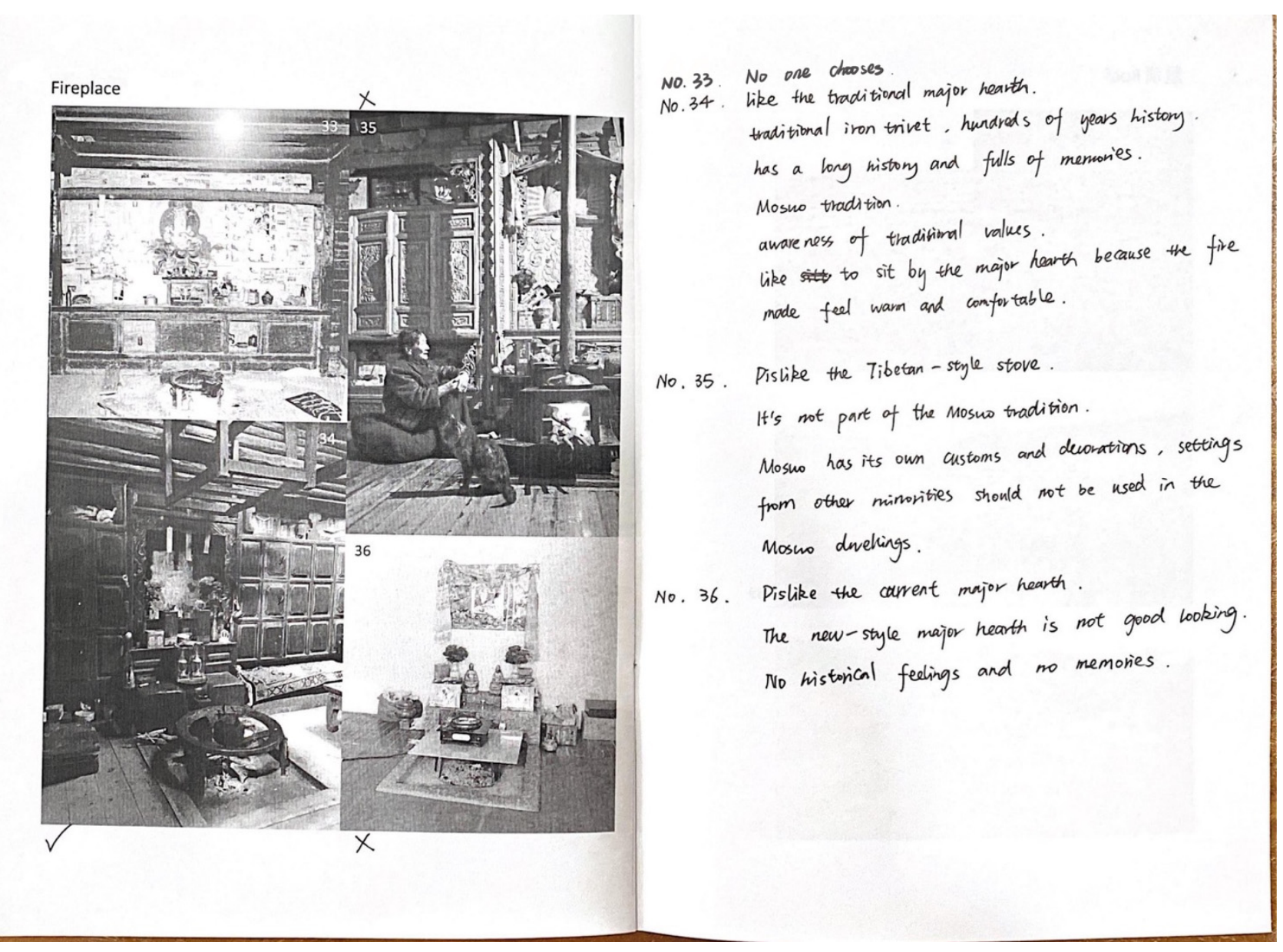

Figure 3. Example of a set of photos and notes on the booklets during the fieldwork.

\section{Results and Discussion}

\subsection{Changes in the Mosuo Dwellings}

The investigation of the changes to the living culture of Mosuo dwellings has showed that there is an increase in the variety of work and a relative decline in the performance of traditional activities. Table 1 shows that Mosuo people aged 18-30 years old and 30-60 years old used to do farm work or household maintenance, but more recently they have started to work as builders or waiters in nearby villages, or as a businesspeople running their own businesses, etc.

There were certain changes in the building culture of Mosuo dwellings, especially site selection, spatial organisation, architectural structure and materials, interior settings and decoration (Table 2). Selection of the site has gradually changed, from building at the foot of a mountain, near the lake or by the river, to being built on either side of the main road of the village. The spatial organisation of today's Mosuo dwellings is more reflective of concerns about hygiene and efficient space utilisation, as reflected in the courtyard layout, the elevation of the houses and the flower house. The changes of architectural structure and materials are mainly reflected in roofs, courtyard paving, and walls, as well as through varying styles of doors and windows. For example, log houses are the most typical traditional Mosuo dwellings, but they are undergoing transformation, and concrete and brick houses are now common. Mosuo dwellings' interior spaces and functions have partly changed on the basis of the continuation of traditional Mosuo culture, such as the Grandmother's house and the sacred chamber. The interior decoration of the Grandmother's house is brighter, more exquisitely carved and more colourful than ever before. 
Table 1. The current changes of ways of living of different age ranges.

\begin{tabular}{|c|c|c|c|}
\hline Age Range & Past Ways of Living & Current Ways of Living & Changes \\
\hline $\begin{array}{l}\text { Under } 18 \\
\text { years old }\end{array}$ & $\begin{array}{l}\text { Light farming work; playing } \\
\text { on the ground in the yard }\end{array}$ & $\begin{array}{l}\text { Go to school to learn knowledge, some } \\
\text { studying in cities and some studying in } \\
\text { nearby villages' school }\end{array}$ & $\begin{array}{c}\text { More access to official education; } \\
\text { influence of outside areas, such as } \\
\text { language }\end{array}$ \\
\hline $\begin{array}{l}\text { 18-30 years } \\
\text { old }\end{array}$ & $\begin{array}{l}\text { Traditional farming work and } \\
\text { housework maintenance; } \\
\text { traditional rites and festivals }\end{array}$ & $\begin{array}{l}\text { Some starting to work in nearby } \\
\text { villages, and some running their } \\
\text { businesses, some working in cities; a } \\
\text { few performing farming activities; } \\
\text { watching TV for entertainment in the } \\
\text { living room }\end{array}$ & $\begin{array}{c}\text { Not many traditional farming activities } \\
\text { performed; modern entertainment } \\
\text { involved in watching TV; the variety of } \\
\text { work increased }\end{array}$ \\
\hline $\begin{array}{l}30-60 \text { years } \\
\text { old }\end{array}$ & $\begin{array}{l}\text { Traditional farming work and } \\
\text { housework maintenance; } \\
\text { traditional rites and festivals }\end{array}$ & $\begin{array}{l}\text { Some starting to work in nearby } \\
\text { villages, and some running their } \\
\text { businesses, some working in cities, } \\
\text { performing farming activities; } \\
\text { traditional rites and festivals; watching } \\
\text { TV for entertainment in the living room }\end{array}$ & $\begin{array}{c}\text { Few farming activities performed; } \\
\text { modern entertainment involved in } \\
\text { watching TV; the variety of work } \\
\text { increased }\end{array}$ \\
\hline $\begin{array}{l}\text { over } 60 \\
\text { years old }\end{array}$ & $\begin{array}{l}\text { Less physically active, light } \\
\text { farming work and housework } \\
\text { maintenance; religious pray }\end{array}$ & $\begin{array}{c}\text { Less physically active, light farming } \\
\text { work and housework maintenance; } \\
\text { religious pray }\end{array}$ & No change \\
\hline
\end{tabular}

Table 2. Summary of changes in the building culture of Mosuo dwellings.

\begin{tabular}{clll}
\hline & \multicolumn{1}{c}{ Traditional Dwellings } & \multicolumn{1}{c}{ Transforming Dwellings } \\
\hline Site selection & $-\quad \begin{array}{l}\text { Built at the foot of the mountain, near the lake or by } \\
\text { the river }\end{array}$ & $\begin{array}{l}\text { Built on either side of the main road of the } \\
\text { village }\end{array}$ \\
\hline Spatial & $-\quad \begin{array}{l}\text { Simple layout: a courtyard plan or 'U-shaped plan'; } \\
\text { organisation }\end{array}$ & $\begin{array}{l}\text { The Grandmother's house merely as a relax, social } \\
\text { and cultural space; } \\
\text { Rooms in the flower house are for sexually active } \\
\text { Mosuo women to practice walking marriage; } \\
\text { No toilet and independent kitchen }\end{array}$ & $\begin{array}{l}\text { Complex building compound: two-entrances } \\
\text { spatial arrangement with two courtyards; } \\
\text { Multi-level buildings of three or four stories; } \\
\text { The Grandmother's house as a living room } \\
\text { with modern facilities but maintaining original } \\
\text { functions or both had a Grandmother's house } \\
\text { and an individual western-style living room; } \\
\text { Rooms in the flower house transformed into a } \\
\text { bedroom or guestroom; } \\
\text { Add kitchen, bathroom and other kinds of } \\
\text { modern living facilities }\end{array}$ \\
\hline
\end{tabular}

- $\quad$ Pitched roofs supported by timber structure and pillars, these used because timber from local;

- Wood shingles (Chinese fir) as roof materials that are

Architectural structure and materials

replaced or repaired yearly at a fixed certain time;

- $\quad$ The inner courtyard is covered original rammed earth or slabs of rock;

- Walls built from log and rammed earth;

- Wooden gates;

- Wooden-framed window

- The grandmother's house consists of five spaces, the main room, the upper room, the lower room, the front room and the back room;

Interior settings and decoration
- The building interior is decorated by the texture and colour of the wood itself;

- A bedroom with simple interior furnishings, only two single beds, no other furniture, walls covered with newspaper flyers and advertising posters
- Flat roofs supported by pre-stressed concrete, these used because timber is expensive and rot;

- Clay tiles as roof materials, easy access for repair;

- The inner courtyard is paved in a hard surface with cast-in-place concrete;

- Walls built of modern brick or concrete;

- Iron gates;

- New style wooden-framed window or aluminum windows

- The grandmother's house has only four spaces, the main room, the upper room, the lower room and the front room;

- $\quad$ The building interior is decorated by the texture and colour of the wood itself;

- A modern bedroom with a TV, wardrobe, a bedside cabinet, a double bed, a lamp, curtains and carpet, etc. 
Regarding the core Mosuo values and beliefs, the main changes are reflected in the strengthening of religious belief, and the increased desire for modern ways of living and financial stability. Tibetan Buddhism has deeply influenced the exterior decoration of new buildings and the interior settings of the grandmother's house, with features including Tibetan-style windows and Tibetan-style stoves (Figure 4).

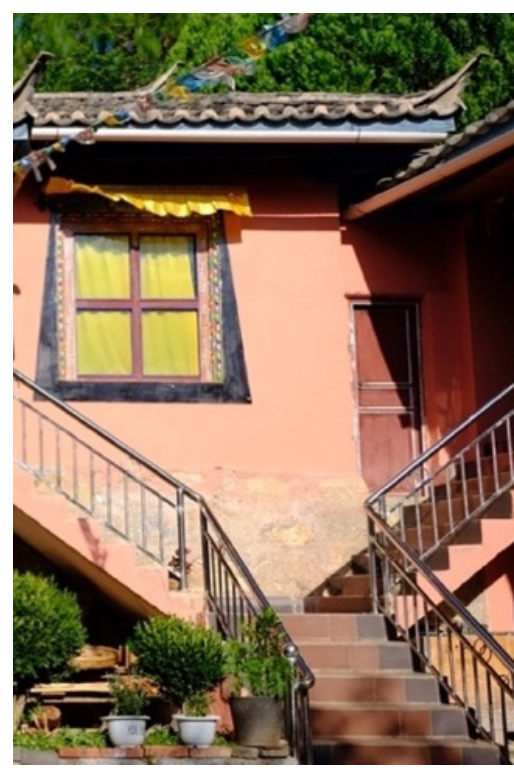

(a)

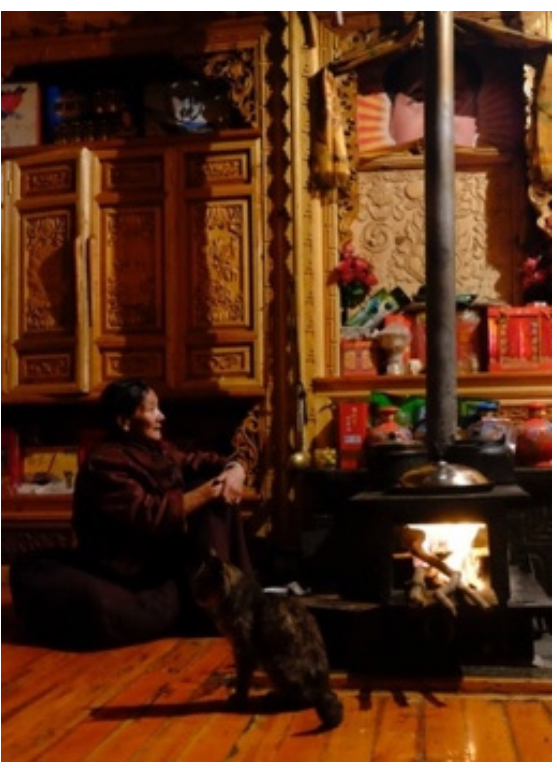

(b)

Figure 4. (a) Tibetan-style windows installed in the current Mosuo dwellings; (b) a Tibetan-style stove appeared in the Mosuo dwellings.

\subsection{Continuities in the Mosuo Dwellings}

Even though the previous analysis reflects the changes of the Mosuo dwellings in the modern era, Mosuo dwellings appear to retain characteristics that are yet unique and meaningful to Mosuo people. Regarding the continuity of living culture within the investigation, it has been shown that, even though adjustments of rural ways of living in the Mosuo region have happened in response to local social and economic changes, the Mosuo still partially retain the intrinsic agrarian lifestyles and matrilineal living patterns of the past.

Additionally, building culture in the Mosuo dwellings has been retained in terms of spatial organisation, architectural structure, and interior decoration-features which are, in particular, reflected in the courtyard form and the grandmother's house. Despite the appearance of multiple courtyards, the courtyard form still exists in today's Mosuo dwellings as an enclosed form (Figure 5). This is because the courtyard mediates all domestic (including living and farming), religious and social activities of the Mosuo families. The courtyard organises buildings in a Mosuo house in an enclosed form that provides privacy and security, symbolising matriarchal harmony. Similarly, most of the architectural and interior settings of the grandmother's house have been preserved in their form, function and meaning, including female and male columns, a major hearth, a Zambala, a Guozhuang stone and a Situo (Figures 6 and 7). 


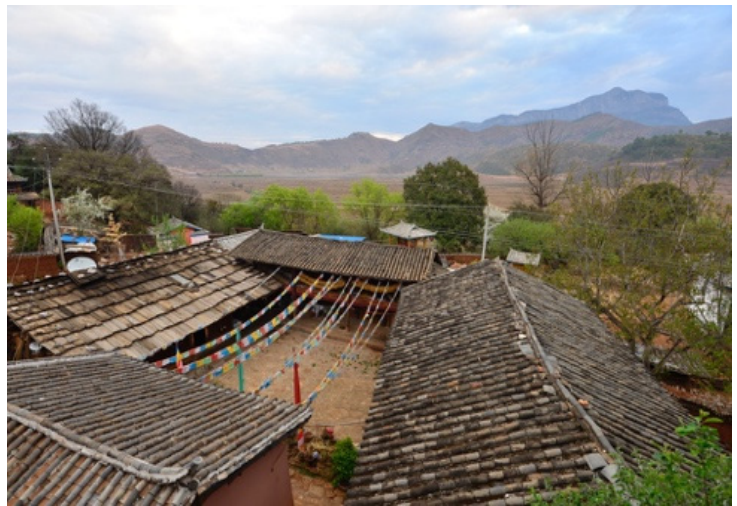

(a)

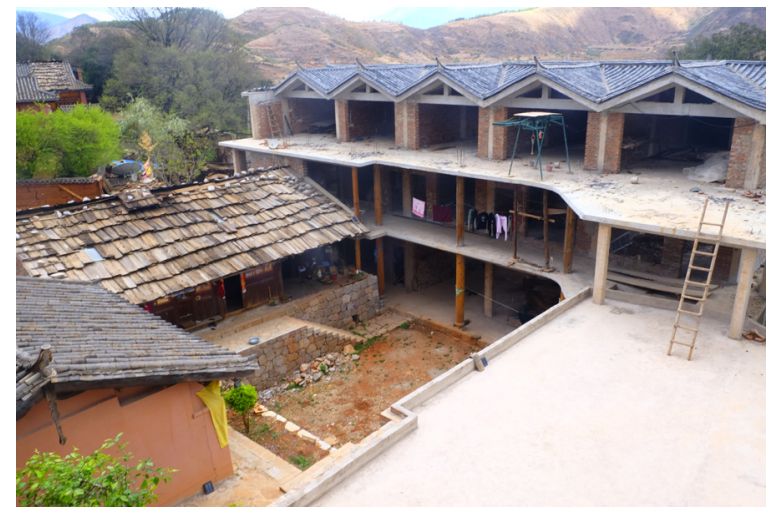

(b)

Figure 5. (a) Traditional courtyard form; (b) present courtyard form.

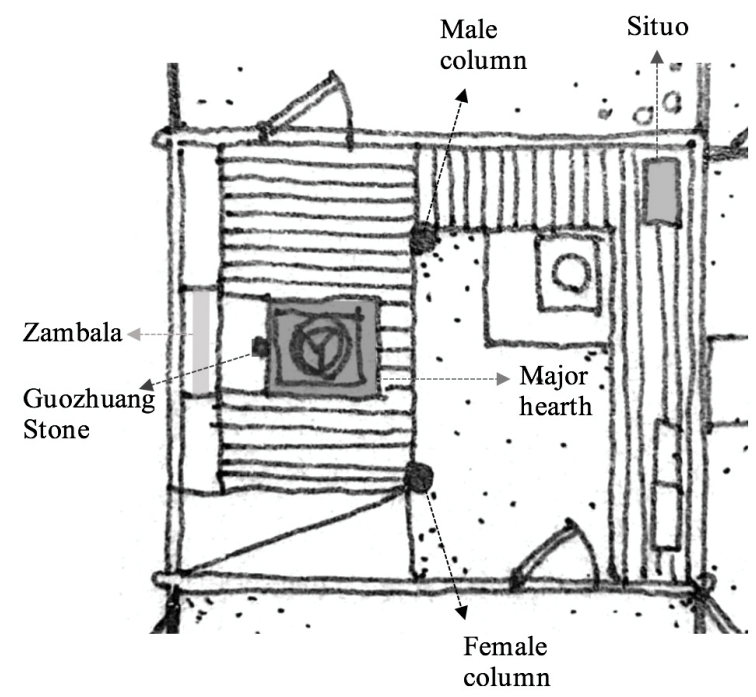

Figure 6. Continuity in room settings within the main room of the grandmother's house.

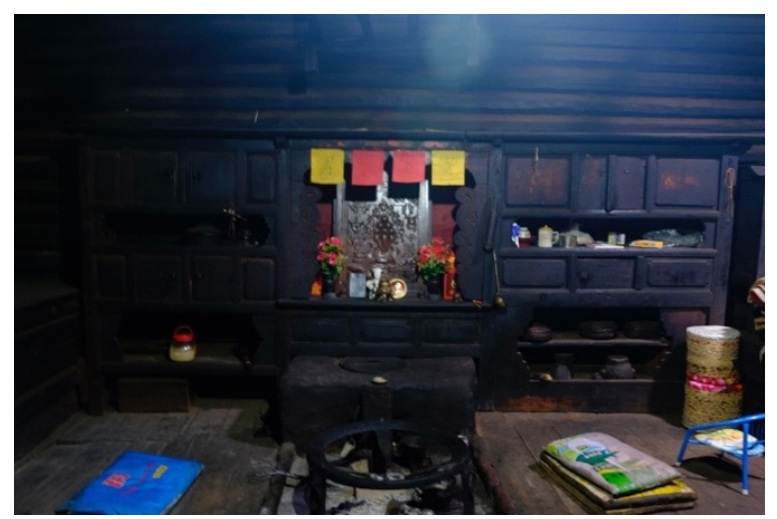

(a)

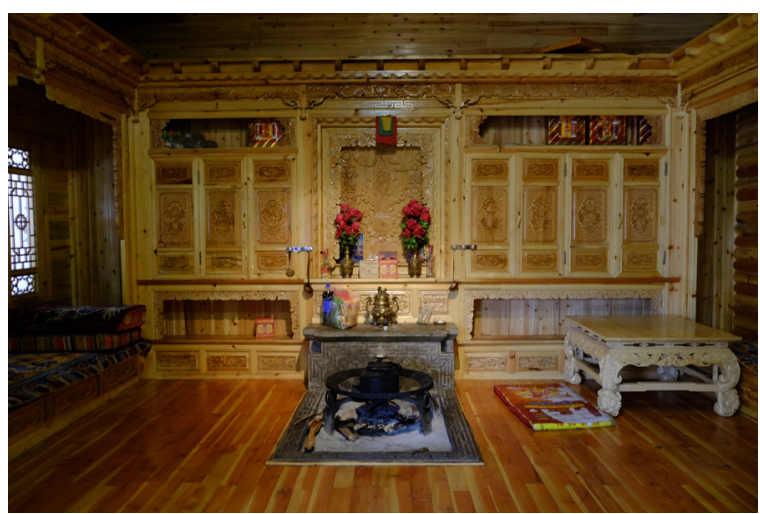

(b)

Figure 7. (a) Interior settings of the old grandmother's house; (b) interior settings of the modern grandmother's house.

As for the continuities of values within the Mosuo dwellings, matriarchal values, religious belief and some traditional values of living are still retained today, such as the continuity of values of the central status of women, as embodied in the continuity of the exterior form and interior decoration of the grandmother's house as well as its function and meaning. 


\subsection{Interpretation of Authenticity in Transitions}

Policy, modernisation and tourism, as external driving forces, have brought about major changes within the Mosuo dwellings, villages and culture. The beliefs, perceptions and desires of Mosuo people have determined the representational forms of the authenticity of their culture and lived spaces. Authenticity of Mosuo dwellings can be interpreted using CAA with a set of components (Figure 8) that is changing and dynamic:

- Living culture-relating to physical interaction and use of architecture, e.g., domestic activities;

- Building culture-physical aspects, including site, spatial organisation of buildings, building structures and constructions, and interior decoration settings;

- Values-relating to human cultural values, beliefs, customs, desires and attachments.

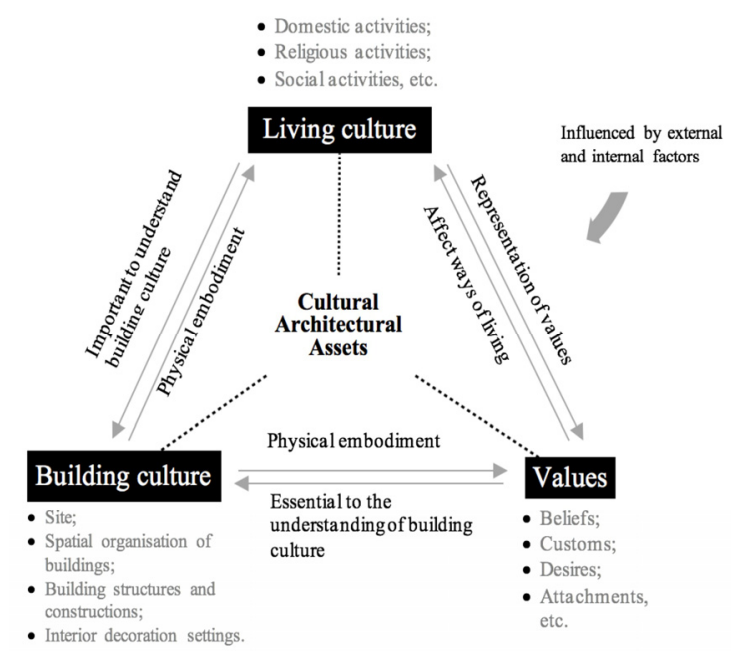

Figure 8. Cultural architectural assets model to interpret authenticity of Mosuo dwellings in transitions.

The dynamic authenticity is the traditions in transitions or something developed out of their culture but, not appeared historical. CAA of the Mosuo dwellings that continue to this day include the courtyard form, the sacred chamber, and the grandmother's house (comprising female and male columns, a major hearth, a Situo, a Guozhuang stone, and a Zambala). It has been noted that the grandmother's house has essentially retained its form, function and meaning in the current dwellings. This is because of its cultural importance, not only as a central place for the daily activities of the Mosuo family members, but also as an embodiment of the values of the central status of Mosuo women and their living values as well. For instance, the main room in the grandmother's house is for the elderly grandmother to sleep in, which indicates that the elderly grandmother is the core of the family and needs the care of the whole family. One respondent's comment impressed me most:

"The meaning of the grandmother's house is to give birth to me, to raise me, to educate me and to give me life. The grandmother's house is a fusion of multiculturalism: the businessman, the farmer, the elderly, monks, infants and the sick coexist in harmony. The cultural roots of the Mosuo are the grandmother's house."

The sacred chamber continues today and even strengthens the religious values of Tibetan Buddhism. The reason for the continuity of this tradition is that the Mosuo people are deeply influenced by Tibetan Buddhism and have formed a strong and enduring belief. As a result, the continuation of traditional values and the carrying out of traditional ways of living retains the usability of original architectural spaces.

One can see that the CAA in the Mosuo dwellings that are in a state of change are the flower house and grass house-where it can be observed that living culture and building culture have considerably altered. This is mainly due to people's pursuit of a clean and 
hygienic living environment and the desire for modern ways of living. For instance, most Mosuo families have now moved the grass house out of the original courtyard and have built another enclosed space nearby, so as to separate people from animals.

The CAA which have gradually disappeared from the Mosuo dwellings are the back room (Dupan) and the upper hearth in the grandmother's house, as well as the wooden shingle roof. This is because under the strong influence of certain perceptions of "modernization", some traditional ways of living have started to disappear from the Mosuo dwellings—such as giving birth at home, or cooking on the upper hearth—and the related spaces (e.g., the back room) or interior settings have begun to be either abandoned or removed. For example, one respondent reflected that:

"There would be other items moving into the grandmother's house later while there would be other things slowly abandoned, like the back room ... Because mothers go to the hospital to give birth instead of giving birth at home now. Another example, there were upper and lower hearths in the past for the convenience of cooking, but now the upper hearth has been removed because they are rarely used in daily life and take up space."

As Abel [56] argued "the essence of architecture as a culture-form especially has to do with the formation of personal, social and cultural identities." The term "cultural architectural assets" is not simply the result of physical forces or any single causal factor, but is the consequence of a series of interactive factors. Analysis of this investigation shows that the interrelations between living culture, building culture and values are strong, in the sense that an understanding of values, including beliefs, customs, desires and attachments, is essential to the understanding of building culture and living culture. Since the form of buildings is the physical embodiment of values, and related behaviour activities are the representation of values, values, once formed, shape the built form and affect ways of living [17]. Maintaining the interrelations between living culture, building culture and values, the authenticity of Mosuo dwellings can be naturally preserved, even in the process of dynamic change- "a natural way of conservation, that is, conservation by living [41]." Nonetheless, if these three relationships are interrupted in the process of change, then changing spaces, unused spaces and abandoned architectural forms emerge in the lived space; as CAA may ultimately disappear, therefore conservation measures regarding changing and disappearing CAA should be developed. This framework is both particular to the context of Mosuo dwellings and general to be adapted to different studies.

\subsection{Sustainable Conservation Responding to Dynamic Authenticity}

As discussed above, the study points out the sustainable living culture, building culture and values and beliefs are most determinant factors in the conservation of the vernacular architecture to keep the authenticity. Whether at the village scale or the dwelling scale, the interrelationship between these factors needs to be considered and maintained in the future conservation and development process. The authenticity, thus, is dynamic adapting to the changes in living cultures, building culture, values and beliefs of the indigenous communities in transitions.

Arising from the previous studies on authenticity, authenticity has been little considered as a dynamic in the conservation of vernacular architecture [57]. The sense is that, if conservation is undertaken with fixed standards, the authenticity of vernacular architecture may be threatened and even interrupted in the constantly changing process [58]. Recently, Kristensen [59] emphasised the social connotations of authenticity referring to the intrinsic value of the original creation. The term "value" is associated with the social valuation of heritage at a given time and place, as the "static authenticity." While the "static" authenticity of vernacular architecture is affected by continuous manifestations that not only evolve in time, but also depend on different contexts. These manifestations of vernacular architecture as opposed to the "static authenticity" can be considered as the "dynamic authenticity." For example, in this study, matriarchal cultural values, religious values and living values are relatively stable, while building values are dynamic. The socio-cultural and living values are reflected in the character of Mosuo dwellings, which 
have to be emphasized and continued in its conservation. Development is inevitable, but what we can do is to keep a sustainable interrelationship between the living culture, socio-cultural values and the changing environments which can naturally be conserved by local inhabitants.

The CAA framework can be used to interpret the dynamic authenticity and to draw out a picture of how others might be able to identify the transitions of authenticity for conservation. What matters most in the authenticity conservation of vernacular architecture is that the properties that are preserved can truly reflect the values [60]. "Values" here means the special level of meaning that elevates, above the ordinary, a thing that people want to keep and pass on to future generations [61]. For example, in this study, they are living, building and socio-cultural values. The grandmother's house not only has the function of living values, but also embodies the unique matriarchal values of the Mosuo people. Although the Mosuo people have no written record of their culture, they represent their ethnic values through the form of their houses. What we expect is that the values placed in the dwellings should be able to be continued alongside evolution, instead of there being copying of foreign buildings and the subsequent disappearance of architectural traditions [62].

In addition to helping explain dynamic authenticity, CAA framework is a proposed framework developed by this research to construct a conservation approach for sustainable development. In recent years many publications have appeared that stress the sustainable character of vernacular architecture [63-65]. The idea of sustainability is to make sure that our decisions and actions today do not compromise future generations to meet their own needs [66]. Instead of returning to traditions and restoring the original forms, this study proposes a set of rigorous conservation approaches, namely, analysing what are continued CAA, changing CAA and disappearing CAA. As a result, CAA draws out a picture how others might be able to identify the transitions of authenticity for conservation, providing a future-facing sense of identity and continuity within a changing world.

Existing local regulations and approaches covering the restoration and maintenance of vernacular architecture do not fully address the challenge of avoiding cultural loss. In China, various "cultural villages" (e.g., world heritage Lijiang Old Town) exist which attract tourists with the chance to experience the rural life of the ethnic people, such as visit traditional dwellings [67]. One of the consequences of commercialisation is that many local residents are increasingly renting out their homes and starting to live elsewhere, drawn by the profit that can be earned by leasing properties [68]. In history, many measures have been taken to ensure the conservation of vernacular architecture. The "open-air museum" was first assembled in Nordic countries at the end of the nineteenth century to save the vernacular buildings from dereliction or destruction and to represent them in situ or in a protected location [69]. However, the display of the "open-air museum" means the petrification of the village without people and cultural activities, which are only conducted in a folkloric way as a display for tourists. This measure interrupts the continuity and the transmission of tradition in living culture. Another way is to transform the traditional buildings into hotels or "boutique hotels" [70]; while buildings can only be physically preserved for decorative purposes and cannot have their original use or cultural structure. This situation brings the interruption in the relations between living culture and values and beliefs; and leads to form a new kind of interpretation of the relations.

The current practice and legislations of conserving vernacular architecture are transforming from cultural relics conservation to heritage conservation [71]. The existing concept of heritage conservation emerged in the late 19th century. The Venice Charter [28] proposed a controversial approach for the conservation and restoration of monuments and sites:

"The conservation of monument implies preserving a setting which is not out of scale. Wherever the traditional setting exists, it must be kept. No new construction, demolition, or modification which would alter the relations of mass and colour must be allowed."

Subsequently, the International Council of Monuments and Sites (ICOMOS) promotes heritage conservation applied to monuments, historic areas and sites. It emphasises 
the importance of setting, respect for original fabric, and the precise documentation of any intervention [72]. Today's heritage conservation involves the actions or processes of maintenance, preservation, restoration, adaptation or combination of any mentioned actions or processes so as to safeguard tangible heritage with reference to its cultural significance such as aesthetic, historic, scientific, social or spiritual values [73]. Heritage conservation is viewed as actions taken to prevent decay and extend life, preserving the existing state of a heritage resource from destruction or change [74].

Although heritage conservation has existed for many years, there are still limitations in the research on vernacular architecture, especially for contemporary vernacular architecture that has cultural value and belong to neither cultural heritage nor architectural heritage (e.g., the case study selected in this study, the Mosuo dwellings and its culture). Regardless of whether the vernacular architecture examples have been selected as cultural heritage or not, they are protected in accordance with the principles of heritage conservation in China at present. As previous discussed, vernacular architecture is always in a state of dynamic process. However, we have yet to apply the changing process toward an understanding of vernacular architecture conservation. In light of this study, it can be argued that vernacular architecture in the changing process should have its own conservation guidance which looks at the dynamic authenticity. A systematic framework needs to be developed to ensure the protection of those physical properties with cultural features in transitions.

In contrast to the current cultural heritage and architectural heritage frameworks, CAA provides a new direction for theory and practice to conserve vernacular architecture in transitions. Cultural heritage refers to tangible and intangible heritage, and architectural heritage refers to material assets. The definition of cultural heritage has been expanded from historical monuments, groups of buildings and sites across the 20th century to the present definition, which includes both tangible and intangible heritage as well as the close interrelations between the two $[29,75,76]$. The early understanding of architectural heritage concerned historical monuments, groups of building and sites [77]; today's definition has expanded to cover groups of buildings, vernacular architecture and 20th-century built heritage [78]. CAA refer to a series of interactive factors regarding living culture, building culture and values. Most research regards architecture as a material/physical representation, without a comprehensive view of architecture as a series of interactive factors [79,80]. CAA also emphasise local distinctiveness, and consist of social, cultural and use value, for a particular group of people or community from a regional perspective.

\section{Conclusions}

In conclusion, the aim of the present research was to define dynamic authenticity and to construct a conservation approach for sustainable development of cultural-architectural elements belonging to this unique vernacular architecture within the changing context of modernity, which supported inhabitants, policymakers and practitioners. It has brought new insights into the sustainability of vernacular architecture in the face of contemporary challenges.

The study has produced an original contribution to our expanding knowledge of conservation through full documentation of the transitions of Mosuo dwellings and its culture in the contemporary context. This has contributed to our understanding of the changes and continuities in the Mosuo dwellings in the evolution process, in terms of the three dimensions of living culture, building culture, and values and beliefs.

This research has gone beyond simple descriptive analysis of the evolution of Mosuo dwellings; more importantly, the originality of this research lies in its cross-disciplinary approach and in the production of a new theoretical framework-cultural architectural assets-for the investigation of vernacular architecture in transition and the authenticity. Cultural architectural assets place emphasis on the dynamism of context as well as the association of such assets with both cultural continuity and social significance; thus, they should not be seen as merely safeguarding the past architectural traditions, but, more importantly, as safeguarding the logic of continuity that all communities or social groups 
regard as their valuable architectural assets. The concept of cultural architectural assets was identified for the first time, which added a further dimension to theories concerned with the interrelationships between architectural form, ways of living and culture in the dynamic context. There are significant implications for developing or applying this work in the future, both nationally and internationally. A suggestion for further investigation is to take advantage of the proposed theoretical approach for application to different case studies of diverse cultural contexts, in order to provide action frameworks, and to consequently lead to the development of the proposed idea of this paper.

Author Contributions: H.F. conceived the research, conducted the fieldwork, analysed the data and wrote the paper; J.X. supervised the paper. All authors have read and agreed to the published version of the manuscript.

Funding: This research was funded by the China Scholarship Council (CSC). The APC was funded by Zhejiang Sci-Tech University.

Institutional Review Board Statement: This study was conducted according to the Birmingham City University Ethical Principles and Practice Policy Statement, and approved by the Academic Ethics Committee of Birmingham City University.

Informed Consent Statement: Informed consent was obtained from all subjects involved in the study.

Data Availability Statement: The datasets generated during and analysed during the current study are available from the corresponding author on reasonable request.

Acknowledgments: The authors acknowledge the help and support on local authority and administrative centres (Administration of the Lugu Lake Tourist Region, etc.), many village leaders and Mosuo inhabitants contacted during the study.

Conflicts of Interest: The authors declare no conflict of interest.

\section{References}

1. Ninglang Yizu Zizhixian Zhi Bianzuan Weiyuanhui (Compiling Committee of Ninglang Yi Autonomous County). Ninglang Yizu Zizhixian Zhi (Ninglang Yi Autonomous County Local Records); Yunnan Nationalities Publishing House: Yunnan, China, 1993.

2. The Lugu Lake Mosuo Cultural Development Association. Matriarchal/Matrilineal Culture. Available online: http://www. mosuoproject.org/matri.html (accessed on 17 November 2016).

3. Walsh, E.R. The Mosuo-Beyond the Myths of Matriarchy: Gender Transformation and Economic Development. Ph.D. Thesis, Temple University, Philadelphia, PA, USA, 2001.

4. Liu, X. Discovering the Mysterious Oriental Kingdom of the Female; Yunnan Nationalities Press: Kunming, China, 2006.

5. Zang, X. Handbook on Ethnic Minorities in China; Edward Elgar Publishing: Cheltenham, UK; Northampton, MA, USA, 2016.

6. Shih, C.K. Mortuary Rituals and Symbols among the Moso. In Naxi and Moso Ethnography. Kin, Rites, Pictographs; Oppitz, M., Hsu, E., Eds.; Cambridge University Press: Zurich, Switzerland, 1998; pp. 103-125.

7. Ma, Q.; Bai, Y.; Che, Z. You Jingshen Yiyi de Juzhu Kongjian Mosuo Minju de Jianzhu Xingtai he Juzhu Wenhua (Residential Space Containing Spirit Contents: Architectural Form and Residential Culture of Mosuo Folk Houses). Huazhong Archit. 2009, 3 , 252-256.

8. Yan, R.; Song, Z. Yongning Naxizu de muxi Zhidu (The Matrilineal System of the Naxi People at Yongning); Yunnan People's Publishing House: Yunnan, China, 1983; p. 151.

9. Shih, C.K. The Yongning Moso: Sexual Union, Household Organization, Gender and Ethnicity in a Matrilineal Duolocal Society in Southwest China. Ph.D. Thesis, Stanford University, Stanford, CA, USA, 1993; pp. 135-147.

10. Cai, H.; Hustvedt, A. A Society without Fathers or Husbands: The Na of China; Zone Books: New York, NY, USA, 2001; pp. 129-139.

11. Wu, Z.; Chen, Y.; Zhao, K.; Ma, W.; Sun, N.; Luo, D. Xinan Minju (Chinese Vernacular House of Southwest China); Tsinghua University Press: Beijing, China, 2010.

12. He, Z. Shengcun he Wenhua de Xuanze: Mosuo Muxizhi ji Xiandai Bianqian (A Choice between Survival and Culture: Mosuo Matriarchal Culture and Modern Change); Education Publishing House: Yunnan, China, 2000; p. 184.

13. Sun, D.Z. Zhongguo Minju Yanjiu (Research on Chinese dwellings); China Architecture Publishing: Beijing, China, 2004

14. Liu, D.Z. Zhongguo Zhuzhai Gaishuo (Chinese Traditional Residence); Architectural Engineering Press: Beijing, China, 1957.

15. Rudofsky, B. Architecture Without Architects: A Short Introduction to Non-Pedigreed Architecture; University of USA New Mexico Press: Bernalillo, NM, USA, 1987.

16. Morgan, L.H. Houses and House Life of the American Aborigines; University of Chicago Press: Chicago, IL, USA, 1965.

17. Rapoport, A. House Form and Culture; Prentice Hall: Englewood Cliffs, NJ, USA, 1969. 
18. Weng, N. The Mother House: The Symbolism and Practices of Gender among the Naxi in Southwest China. Ph.D. Thesis, University of Rochester, Rochester, NY, USA, 1993; pp. 22-23.

19. Waterson, R. The Living House: An Anthropology of Architecture in South-East Asia; Thames \& Hudson: London, UK, 1998.

20. Pan, X. Research on the Building Paradigm of Naxi Vernacular architecture. Ph.D. Thesis, Tsinghua University, Beijing, China, 2014.

21. Gao, Y.; Pitts, A. Sustainable Building Practice and Guidance for Dai Villages, Southwest China. In Proceedings of the PLEA (Passive and Low Energy Architecture) Conference 2018: Smart and Healthy within the 2-Degree Limit, Hong Kong, China, 10-12 December 2018; pp. 1103-1104.

22. Knapp, R.G. China's Traditional Rural Architecture: A Cultural Geography of the Common House; University of Hawaii Press: Honolulu, HI, USA, 1986.

23. Ma, Q. The wooden house by the Lugu Lake (Qicai Yunnan zhi Shijiu Luguhu bian de Mulengfang). ID+C Inter. Des. Constr. 2001, 12, 92-96.

24. Liu, S.; Li, F. Mosuo Yishu (Mosuo Art); Sichuan Fine Arts Press: Chengdu, China, 2005; pp. 72-103.

25. Nezhad, S.F.; Eshrati, P.; Eshrati, D. A Definition of Authenticity Concept in Conservation of Cultural Landscapes. Int. J. Archit. Res. ArchNet-IJAR 2015, 9, 93-107. [CrossRef]

26. Ulukan, M.; Arslan, H. Developing a New Authenticity Rating System on Architectural Conservation. Sustain. City 2012, 2, 1235-1244.

27. Assi, E. Searching for the Concept of Authenticity: Implementation Guidelines. J. Archit. Conserv. 2000, 6, 60-69. [CrossRef]

28. International Charter for the Conservation and Restoration of Monuments and Sites. Available online: https://www.icomos.org/ charters/charters.pdf (accessed on 12 September 2019).

29. Convention Concerning the Protection of the World Cultural and Natural Heritage. Available online: https:/ / whc.unesco.org/ archive/convention-en.pdf (accessed on 16 December 2020).

30. Operational Guidelines for the World Heritage Committee. Available online: http://whc.unesco.org/archive/opguide77a.pdf (accessed on 24 December 2020).

31. The Nara Document on Authenticity. Available online: https:/ / www.icomos.org/charters/nara-e.pdf (accessed on 20 June 2019 ).

32. Operational Guidelines for the Implementation of the World Heritage Convention. Available online: http: / / whc.unesco.org/ archive/opguide05-en.pdf (accessed on 20 June 2020).

33. Lefebvre, H. The Production of Space; Wiley-Blackwell: Hoboken, NJ, USA, 1991; pp. 38-39.

34. Tylor, E.B. Primitive Culture; Peter Smith Publisher: Gloucester, MA, USA, 1871.

35. Oliver, P. Dwellings: The House Across the World; Phaidon: Oxford, UK, 1987; pp. 7-15.

36. Malinowski, B. A Scientific Theory of Culture; Chapel Hill, The University of North Carolina Press: New York, NY, USA, 1944.

37. Rapoport, A. Culture, Architecture, and Design; Locke Science Pub. Co.: Chicago, IL, USA, 2005.

38. Rapoport, A. Thirty-Three Papers in Environment Behaviour Research; Urban International Press: Newcastle, UK, 1995; pp. 399-436.

39. Karakul, Ö. Folk Architecture in Historic Environments: Living Spaces for Intangible Cultural Heritage. Milli Folklor Int. Q. J. Cult. Stud. 2007, 19, 151-163.

40. Oliver, P. Cultural Traits and Environmental Contexts-Problems of Cultural Specificity and Cross-Cultural Comparability. In Proceedings of the International Symposium Culture and Space in the Home Environment, Critical Evaluations and New Paradigms, ITU, Faculty of Architecture in Collaboration with IAPS, Istanbul, Turkey, 4-7 June 1997.

41. Karakul, Ö. A Holistic Approach to Historic Environments: Integrating Tangible and Intangible Values; LAP LAMBERT Academic Publishing: Saarbrücken, Germany, 2013; pp. 44-45.

42. Altman, I.; Chemers, M.M. Culture and Environment; Cambridge University Press: Cambridge, UK, 1984.

43. Mitchell, D. Cultural Geography: A Critical Introduction; Blackwell Publishers: Oxford, UK, 2000.

44. Kenney, S.F. Cultural Influences on Architecture. Ph.D. Thesis, Texas Tech University, Lubbock, TX, USA, 1994; pp. 2-3.

45. Oranratmanee, R. Rural Homestay: Interrelations between Space, Social Interaction and Meaning in Northern Thailand. Ph.D. Thesis, Oxford Brookes University, Oxford, UK, 2008; pp. 51-53.

46. Vellinga, M. A Conversation with Architects: Paul Oliver and the Anthropology of Shelter. Archit. Theory Rev. 2017, 21, 9-26. [CrossRef]

47. Fetterman, D.M. Ethnography: Step-by-Step; Sage Publications: London, UK, 2009.

48. Groat, L.N.; Wang, D. Architectural Research Methods; John Wiley and Sons: New York, NY, USA, 2002.

49. Statistics Bureau of Ninglang County. Ninglang Yi Autonomous County Local Records (Ninglang Yizu Zizhixian Zhi); Yunnan Nationalities Publishing House: Yunnan, China, 2003.

50. Walsh, E.R. From Nü Guo to Nü'er Guo: Negotiating desire in the land of the Mosuo. Mod. Chin. 2005, 31, 448-486. [CrossRef]

51. Mason, J. Qualitative Researching, 2nd ed.; Sage Publications: Thousand Oaks, CA, USA, 2002.

52. Schwartz, D. Visual ethnography: Using photography in qualitative research. Q. Sociol. 1989, 12, 119-154. [CrossRef]

53. Thomas, M.E. Auto-Photography; The Ohio State University: Columbus, OH, USA, 2009.

54. Harper, D. Talking about Pictures: A Case for Photo Elicitation. Vis. Stud. 2002, 17, 13-26. [CrossRef]

55. Shih, C.K. Quest for Harmony: The Moso Traditions of Sexual Union and Family Life; Stanford University Press: Stanford, CA, USA, 2010.

56. Abel, C. Architecture and Identity: Responses to Cultural and Technological Change, 3rd ed.; Routledge: London, UK, $2017 ;$ p. 144. 
57. García-Esparza, J.A. Are World Heritage Concepts of Integrity and Authenticity Lacking in Dynamism? A Critical Approach to Mediterranean Autotopic Landscapes. Landsc. Res. 2018, 6, 817-830. [CrossRef]

58. Garcia-Esparza, J. Clarifying Dynamic Authenticity in Cultural Heritage. A Look at Vernacular Built Environments. ICOMOS Univ. Forum 2018, 1, 1-12.

59. Kristensen, T.M. Pilgrimage, Devotional Practices and the Consumption of Sacred Places in Ancient Egypt and Contemporary Syria. Int. J. Herit. Stud. 2015, 21, 354-368. [CrossRef]

60. Huang, Y.W. Wenhua Yichan Baohu de Xing yu Shen Cong Shaxi Fuxing Gongcheng Shijian Fansi Baohu yu Fazhan de Guanxi (Cultural Heritage Conservation: Reflection on the Relationship between Conservation and Development from Shaxi Rehabilitation Project). Archit. J. 2012, 6, 50-57.

61. Idilfitri, S. Understanding the Significance of Cultural Attribution. Anthropology 2016, 4, 163-168. [CrossRef]

62. Zhu, L.Z. Chuantong Minju Jiazhi yu Chuancheng (The Value and Inheritance of Traditional Dwellings); China Architecture and Building Press: Beijing, China, 2011.

63. Asquith, L.; Vellinga, M. Vernacular Architecture in the Twenty-First Century: Theory, Education, and Practice; Taylor \& Francis: Oxon, UK, 2006.

64. Chiu, R.L.H. Sustainability. In International Encyclopedia of Housing and Home; Smith, S.J., Ed.; Elsevier: Amsterdam, The Netherlands; London, UK; New York, NY, USA, 2012.

65. Vellinga, M. Vernacular architecture and sustainability: Two or three lessons. In Vernacular Architecture: Towards a Sustainable Future; Mileto, C., García Soriano, L., Vegas, F., Eds.; Taylor \& Francis Group: London, UK, 2015.

66. Salman, M. Sustainability and Vernacular Architecture: Rethinking What Identity Is'. In Urban and Architectural Heritage Conservation within Sustainability; Hmood, K., Ed.; IntechOpen: London, UK, 2019. [CrossRef]

67. Yang, F. Ethnic Heritage in Yunnan: Contradictions and Challenges. In Reconsidering Cultural Heritage in East Asia; Matsuda, A., Mengoni, L.E., Eds.; Ubiquity Press: London, UK, 2016; pp. 87-102.

68. Yang, F. Some Problems in the Development of the Tourism in Yunnan. Soc. Sci. Yunnan 2004, 3, 45-48.

69. Oliver, P. Re-presenting and Representing the Vernacular: The Open-air Museum. Tradit. Dwell. Settl. Rev. 1998, $10,73-74$.

70. Can, S..G. A Critical Assesment for Reuse of Traditional Dwellings as “Boutique Hotels" in Urgup. Master's Dissertation, METU, Ankara, Turkey, 2007. Unpublished.

71. Conservation of Vernacular Buildings. Available online: http:/ / www.bjchp.org (accessed on 26 April 2019).

72. Resolutions on the Regeneration of Historic Urban Sites. Available online: https://www.icomos.org/publications/93towns7.pdf (accessed on 15 September 2020).

73. The Burra Charter: The Australia ICOMOS Charter for Places of Cultural Significance. Available online: http:/ / openarchive. icomos.org/2145/ (accessed on 18 September 2020).

74. Feilden, B.M. Conservation of Historic Buildings; Architectural Press: New York, NY, USA, 1982.

75. Blake, J. On Defining the Cultural Heritage. Int. Comp. Law Q. 2000, 49, 61-85. [CrossRef]

76. Convention for the Safeguarding of the Intangible Cultural Heritage. Available online: http://portal.unesco.org/en/ev.phpURL_ ID=17716\&URL_DO=DO_TOPIC\&URL_SECTION=201.html (accessed on 12 May 2020).

77. Convention for the Protection of the Architectural Heritage of Europe: Granada. Available online: https://rm.coe.int/168007a087 (accessed on 19 May 2020).

78. Mounir, B. The Interdependency of the Tangible and Intangible Cultural Heritage. In Proceedings of the 14th ICOMOS General Assembly and Scientific Symposium, Victoria Falls, Zimbabwe, 27-31 October 2003; pp. 1-5.

79. Steinberg, F. Conservation and Rehabilitation of Urban Heritage in Developing Countries. Habitat Int. 1996, $20,463-475$. [CrossRef]

80. Mihaila, M. City Architecture as Cultural Ingredient. Proc. Soc. Behav. Sci. 2014, 149, 565-569. [CrossRef] 